G. Emmi, et al., Int. J. of Energy Prod. \& Mgmt., Vol. 1, No. 4 (2016) 382-392

\title{
MULTI-SOURCE HEAT PUMP COUPLED WITH A PHOTOVOLTAIC THERMAL (PVT) HYBRID SOLAR COLLECTORS TECHNOLOGY: A CASE STUDY IN RESIDENTIAL APPLICATION
}

\author{
GIUSEPPE EMMI, CHIARA TISATO, ANGELO ZARRELLA \& MICHELE DE CARLI \\ Department of Industrial Engineering - DII, University of Padova, Italy.
}

\begin{abstract}
Nowadays the heat pump technology is an efficient solution in the residential sector since it allows to reduce $\mathrm{CO}_{2}$ emissions and to exploit renewable energy sources. At the same time, the solar energy is the renewable source for excellence.

In this study, different combinations of a photovoltaic thermal hybrid solar collector (PVT) and a multi-source heat pump for space heating and domestic hot water (DHW) production have been investigated. The air, solar and ground heat sources for the heat pump were analysed. The case study regards the heat demand of a single-family house building located in north-east of Italy. The considered system configurations have been investigated by means of the simulation tool TRNSYS coupled to a dedicated mathematical model for the estimation of the electrical and thermal performances of solar panels. This model is based on the equivalent electrical circuit.

As a result, all the investigated multi-source systems reported an increase of energy efficiency between $14 \%$ and $26 \%$ compared to a standard air to water heat pump system. The system with air and solar sources has an energy efficiency equal to 3.64, slightly lower than that obtained for the more complex systems.

Keywords: geothermal energy, multi-source heat pump, PVT, solar energy.
\end{abstract}

\section{INTRODUCTION}

Global warming, mainly due to human activities and greenhouse gas emission, has pushed to develop new air conditioning systems, obtained from the combination of different components and the use of renewable energy sources. Residential buildings are responsible for a significant part of greenhouse gas emissions. In Italy, ISPRA [1] revealed for year 2012 an impact on emissions of $18.5 \%$ caused by the residential field. In this context, the heat heat pump technology plays a key role in improving energy efficiency and reducing fossil fuel usage through the exploitation of heat sources at low temperature, which are otherwise not usable for space heating and domestic hot water (DHW) production.

Nowadays, the most common heat pump technology uses the external air as the heat source, because a low initial investment is required and it can be used everywhere. However, operating costs are higher due to the variability of the air temperature and defrosting cycles. Ground Source Heat Pump (GSHP) technology requires high initial investments but can ensure lower operating costs due to the constant ground temperature. However, the ground energy exploitation can cause the so-called thermal drift [2]: if load profiles are heating-dominated, heat extraction from the ground involves its temperature decrease; on the other hand, if load profiles are cooling-dominated, mean ground temperature increases. Therefore, the heat pump's long-term efficiency decreases. To minimize the thermal drift, three possibilities are usually used [3]: an increase of borehole length, usage of hybrid systems coupled with existing components, such as cooling towers in the case of coolingdominated buildings and auxiliary heat generation components for heating-dominated 
buildings, and the combination of solar collectors with GSHPs. This latter represents the most promising and investigated solution in the case of heating-dominated load profiles and makes the decrease of the total borehole length possible, with a consequent reduction of the investment costs.

The combination of a GSHP with a solar system can be realized in different ways. Eslami-nejad et al. [4] investigated single and multiple borehole configurations; in the first case, a U-tube heat exchanger was linked to thermal solar collectors, intended to prepare DHW, and the other one was linked to a GSHP, intended to heat the building. When a surplus of solar energy was available, solar heat was injected by means of the borehole into the ground. Through TRNSYS simulations, it was established that solar injection in a single borehole did not achieve an appreciable increase in heat pump efficiency, whereas it was really efficient in the multiple borehole configuration.

Kjellsson et al. [5] analysed different alternative systems for DHW and space heating, with combinations of solar collectors and GSHPs. By means of TRNSYS simulations, they concluded that the optimal design to decrease the consumption of electricity of the system is when solar heat produces DHW during summertime and recharges the borehole during wintertime.

Hawlader et al. [6] performed analytical and experimental studies on a solar assisted heat pump located in Singapore, where solar collectors acted as the evaporator of a heat pump. The results outlined that the thermal performance of the system was strongly affected by solar radiation, collector area, storage volume where the condenser was installed, and the speed of the compressor.

Indirect use of solar heat by means of heat pump technology allows the installation of low temperature solar systems, such as unglazed thermal collectors or PVT solar panels.

Dott et al. [7] have conducted a simulation study to compare nine possible heating systems supplying space heat and DHW by means of both heat pump and solar systems. For the same roof surface, some of the system configurations considered covered flat plate collectors, others the juxtaposition of thermal and photovoltaic panels, the last one PVT panels. The highest seasonal energy performance of the heat pump was found in the case with PVT panels, which also generated the highest amount of electricity.

Bakker et al. [8] simulated by means of TRNSYS a solar assisted GSHP system with $25 \mathrm{~m}^{2}$ of PVT panels. PVT panels could provide heat to a storage vessel for a direct use or to the evaporator of the GSHP. The authors found that the system was able to cover the total heat demand of DHW and space heating of a one-family dwelling, and $96 \%$ of its electricity use. Furthermore, thanks to the recharge of the ground due to solar heat injection, the mean ground temperature was kept constant, avoiding the decrease of the energy efficiency of the heat pump. Another advantage of this operation was the cooling of the PVT panels, with a consequent increase of the electricity production.

\section{THE CASE STUDY}

This paper investigates four plant system configurations for space heating and DHW production of a residential building located in the city of Vicenza in the north-east of Italy. The configurations have been obtained through the combination of heat pump technology with different heat sources as air, solar and ground. Therefore, special focus is paid on the heat source of the heat pump. The schemes of the systems are represented in Fig. 1.

All the investigated case studies present an air-to-water heat pump coupled to a waterto-water heat pump. The choice between the two heat pumps is made, for each time-step, evaluating the highest energy efficiency. 


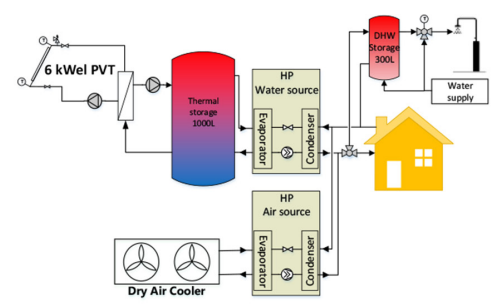

Case A

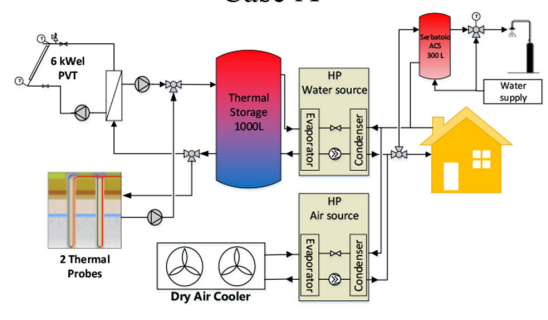

Case C

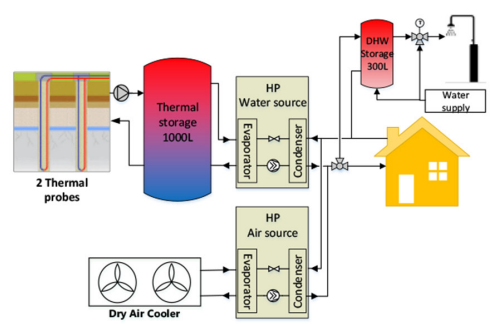

Case B

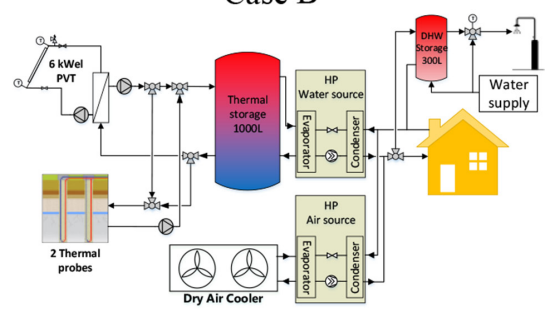

Case D

Figure 1: Configurations of the plant system.

In the Case A the heat source for the water-to-water heat pump was provided by a $6 \mathrm{~kW}$ PVT solar collector field while in the Case B the solar field was replaced by two $30 \mathrm{~m}$ long vertical borehole heat exchangers. In the Case $\mathrm{C}$, solar and ground sources were simultaneously used. In this case, at each time-step, a suitable control strategy was implemented to choose the heat source to be used by the heat pump. In daytime the heat is usually provided by PVT panels, whereas during the night and when solar radiation is low the heat is often provided by the ground source.

Special focus was paid on the most complex system, i.e. the Case D. This case study is different from the previous ones since it provides for the possibility of balancing ground load: during the heating period, the heat is extracted from the ground, whereas during summer the surplus of thermal solar energy is injected into the ground.

\section{METHOD}

The main objective of this work is the evaluation of the energy performances of different multisource systems to provide heating and DHW of a dwelling. As reference, the results were compared also with a standard air-to-water heat pump which represents the reference system.

The first phase of the present work involves the development of a mathematical model in Matlab. It describes the solar panels thermal behaviour depending on the weather and operating conditions, so that thermal and electrical performances can be evaluated. Then, the model has been coupled with TRNSYS by means of a dedicated Type (i.e. Type 155) able to call the Matlab program during each time step.

The second phase consists of dynamic simulations, which have been carried out using the TRNSYS tool, in order to obtain and compare the system configurations energy performances.

An energy analysis requires weather data, building load profile and DHW consumption, characteristics of the plant and its components, control strategies. The main components are the water-to-water heat pump, the air-to-water heat pump, the solar PVT collectors, the borehole heat exchangers, and the storage tank. Borehole heat exchangers were simulated with 
existing TRNSYS type 557, whereas mathematical models developed in Matlab were implemented for the both heat pumps and PVT solar panels. The storage tanks have been simulated with the model present in the TRNSYS code (i.e. Type 4 for the "Thermal Storage" and Type 534 for the "DHW Storage" in Fig. 1 respectively).

Two vertical borehole heat exchangers were considered. They are $30 \mathrm{~m}$ long and $6 \mathrm{~m}$ spaced apart. The short total length of $60 \mathrm{~m}$ is due to the relatively low heating load profile of the building. As for the solar array, unglazed PVT roll-bond panels were selected (an example of this component is shown in Fig. 2); they are made of a photovoltaic panel in the back of which a roll-bond aluminium plate heat exchanger is applied. This heat exchanger consists in very narrow channels where the heat-carrier fluid, a propylene glycol-water solution, flows. No insulation is present in the rear part of the aluminium plate, therefore high temperatures cannot be achieved. In this study, a $6 \mathrm{kWp}$ solar panel installation was chosen, for a total surface of about $40 \mathrm{~m}^{2}$. Such a size allows to meet all the electricity demand of the system, including auxiliaries. Moreover, when ground recharge is considered, it assures the balance of the ground load.

The annual electricity production of the analysed PVT solar array was also compared with that of the same solar array with no roll-bond plate heat exchanger.

The storage tank is the core of the whole system and it is a key component when the energy source is extremely variable and unforeseeable. Thanks to the storage tank it is possible to temporally split the production and demand of energy. In this study, the storage volume of the tank was one cubic meter, which is a compromise between inertia effect and space issues.

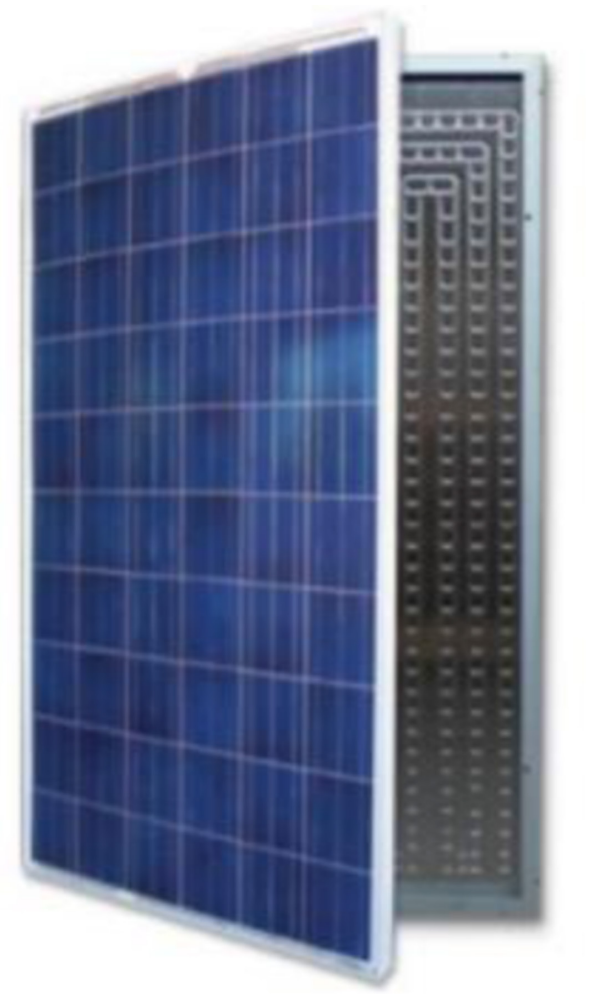

Figure 2: Example of PVT roll-bond panel [9]. 


\section{THE MATHEMATICAL MODEL FOR THE PVT SOLAR COLLECTORS}

A mathematical model has been developed in Matlab to evaluate thermal and electrical performances of the considered PVT panels. The panels mainly consist of three layers: the upper glass of $3.2 \mathrm{~mm}$ of thickness, the photovoltaic sandwich, made of 60 polysilicon cells, and the aluminum roll-bond microchannel plate. No air gaps are present between layers and no insulation exists on the back side of the panel. The mathematical model is based on energy balances of each component of the unglazed PVT system.

Chow [10] analyzed a PVT collector by means of a complex tridimensional dynamic model, based on the finite-difference approach. Simplified approaches based on 1-D models have been developed by some researchers [11-13]. They introduced some simplifications such as negligible heat losses at the edges of the panel, constant physical properties of components, perfect contact between the PV sandwich and the plate heat exchanger below, sky as a black body. In this work the same previous hypotheses have been used.

Energy fluxes involved in the overall system balance are shown in Fig. 3, whereas Fig. 4 outlines a scheme of thermal resistances due to heat conduction, convection and radiation.

The input parameters are the intensity and angle of incidence of solar radiation, air temperature, sky temperature, wind velocity, inlet temperature and mass flow rate of the heat-carrier fluid. The energy balance at each node is written and then the system of equations is solved. As a consequence, the model calculates the useful heat rate, the electrical power, the outlet

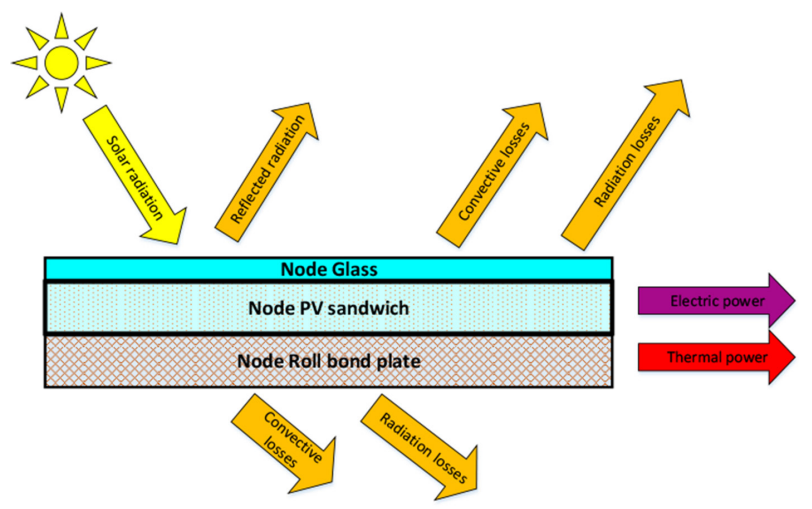

Figure 3: Scheme of the energy fluxes involved in the PTV model.

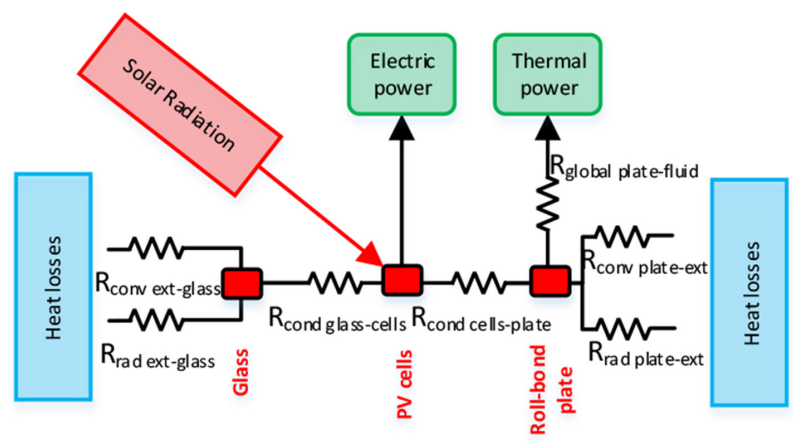

Figure 4: Electrical equivalent circuit of the PVT model. 
temperature of the heat-carrier fluid and the temperature of each node of the PVT device. In particular, the outlet fluid temperature can be calculated by the following equation:

$$
T_{\text {fluid,out }}=\frac{U_{\text {fluid-plate }} \cdot A_{\text {exchange }} \cdot \frac{T_{\text {plate }}-T_{\text {fluid,in }}}{2}+m_{\text {fluid }} \cdot c p_{\text {fluid }} \cdot T_{\text {fluid,in }}}{U_{\text {fluid-plate }} \cdot \frac{A_{\text {exchange }}}{2}+m_{\text {fluid }} \cdot c p_{\text {fluid }}}
$$

The calculation method is an iterative process. At the beginning, initial values of the temperature of glass, cells and plate are set, so that electrical power, and total heat fluxes due to convection and radiation exchanges can be calculated.

The electrical properties of the PV module used in the simulations are typical of a polycrystalline panel, considering the effect of the cell temperature on the electrical power [14].

\section{THE HEAT PUMP MODEL}

To analyze the thermal performance of the heat pumps and to manage their control, a Matlab code has been developed. The input parameters are: inlet temperature and mass flow rate at the evaporator side, inlet temperature and mass flow rate at the condenser side, ambient air temperature and heating demand of the building. The output parameters are the outlet temperatures at the evaporator and condenser side, electric consumption and energy efficiency (i.e. COP).

The choice of the heat source (air or water) depends on the COP values of the two heat pumps at each simulation time-step, which was set to 15 minutes. Table 1 summarizes the main properties of the heat pumps.

\section{THE BUILDING}

The building is a single family-house with a total floor surface of $108 \mathrm{~m}^{2}$ and well insulated walls and windows. The building load profile is shown in Fig. 5 and the total energy needed for heating

Table 1: Properties of the heat pumps.

\begin{tabular}{lccccccc}
\hline & & \multicolumn{5}{c}{ Fluid temperature at condenser [ $\left.{ }^{\circ} \mathrm{C}\right]$} \\
\cline { 3 - 8 } & & \multicolumn{5}{c}{45} \\
\hline & $\begin{array}{l}\text { Fluid temperature at } \\
\text { evaporator }\left[{ }^{\circ} \mathrm{C}\right]\end{array}$ & $\begin{array}{c}\mathrm{P}_{\mathrm{el}} \\
{[\mathrm{kW}]}\end{array}$ & $\begin{array}{c}\mathrm{Q}_{\mathrm{MAX}} \\
{[\mathrm{kW}]}\end{array}$ & $\begin{array}{c}\mathrm{COP} \\
{[-]}\end{array}$ & $\begin{array}{c}\mathrm{P}_{\mathrm{el}} \\
{[\mathrm{kW}]}\end{array}$ & $\begin{array}{c}\mathrm{Q}_{\mathrm{MAX}} \\
{[\mathrm{kW}]}\end{array}$ & $\mathrm{COP}$ \\
\hline W-W HP & 0 & 2.04 & 7.39 & 3.62 & 2.51 & 7.13 & 2.84 \\
Water 70\% & 10 & 2.03 & 9.7 & 4.78 & 2.52 & 9.25 & 3.67 \\
Glycol 30\% & 25 & 2.08 & 13.6 & 6.54 & 2.56 & 12.5 & 4.88 \\
A-W HP & -7 & 1.73 & 3.85 & 2.23 & 1.94 & 3.6 & 1.86 \\
& 2 & 2.02 & 5.15 & 2.55 & 2.21 & 4.86 & 2.20 \\
Air & 10 & 2.33 & 8.03 & 3.45 & 2.53 & 7.25 & 2.87 \\
\hline
\end{tabular}

$\mathrm{P}_{\mathrm{el}}$ : Absorbed electrical power

$\mathrm{Q}_{\mathrm{MAX}}$ : maximum thermal capacity

COP: Coefficient of Performance 


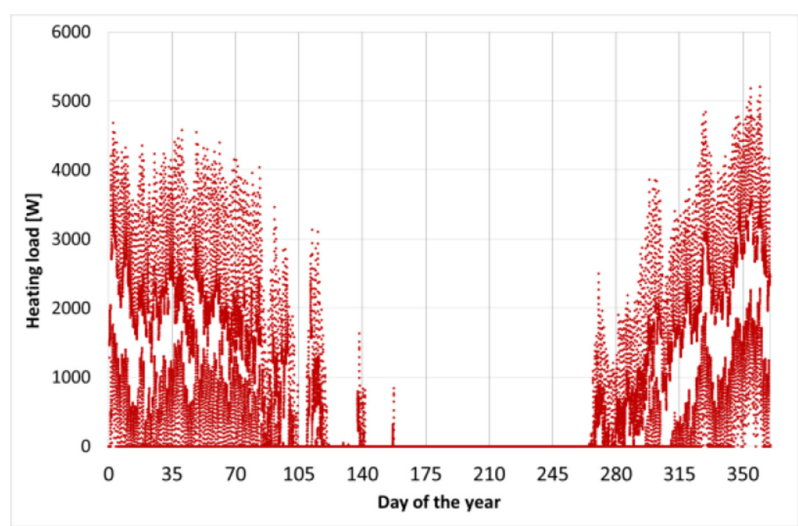

Figure 5: Building load profile.

is 5,622 $\mathrm{kWh} / \mathrm{y}$. The building is located in the E Italian climate zone, which has 2,371 DD and the heating period is from the 15th of October to the 15th of April. Test reference year of Vicenza has been used [15]. As for the DHW demand, a mean load volume of 200 L/day was chosen, considering 4 people living the single family-house. The DHW-load profiles with a time-step of 15 minutes were taken from the IEA Annex 42 report [16]. In this study the temperatures of the municipality water and hot water production were set to $10^{\circ} \mathrm{C}$ and $45^{\circ} \mathrm{C}$, respectively.

\section{RESULTS AND DISCUSSION}

In this section, the main simulation results are reported and discussed. Table 2 shows the values of the total annual useful heat and electric energy produced by the PVT panels with the corresponding energy efficiencies, heat extraction and injection rates of the borehole heat exchangers, the mean ground temperature, the electric consumption of the two heat pumps and finally the seasonal COP of the system (i.e. the ratio between the building energy demand and the electrical consumption of the two heat pumps).

As it can be seen, the thermal efficiency of the PVT system is quite low. This is due to the absence of insulation in the rear part of the heat exchanger, and the type of the PVT device, which is unglazed. The thermal efficiency is referred to the whole PVT system, therefore, it is a mean value that considers the increase of the cell temperature and the consequent decrease of efficiency from the first to the last module of the series.

In Case A, where just solar and air sources are present, the electric efficiency of the PVT system is equal to $15 \%$, which is also the reference efficiency provided by the manufacturer. This is an annual mean value, since it ranges from $14.4 \%$ obtained in July, to $16.5 \%$ in December. Such a value has been compared to that obtained, with the same boundary conditions, from the simulation of a corresponding PV system without the rear heat exchanger; the increase of annual efficiency of the PVT solar field, due to the cooling of the panels, is of about $1 \%$. This low value is due to the fact that the entering fluid temperature to the solar heat exchanger is not always low to sufficiently cool it. That occurs especially in summer, when the load profile is just related to the DHW demand and the mean temperature of the storage tank is often higher than $25^{\circ} \mathrm{C}$.

The temperature of the fluid from the PVT roll-bond plate achieves a maximum temperature of $60^{\circ} \mathrm{C}$ throughout the year and a minimum temperature of about $-10^{\circ} \mathrm{C}$, which is lower 
Table 2: Results of the simulations.

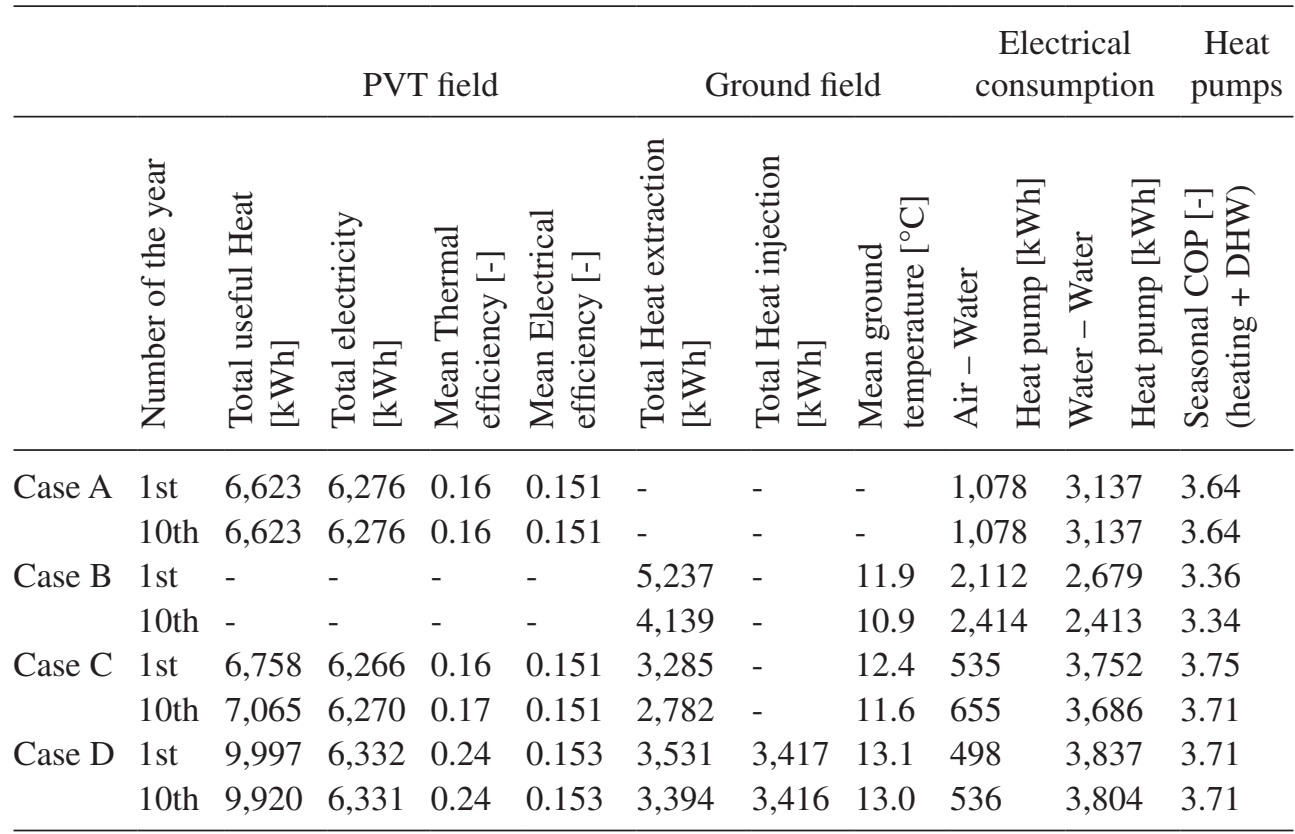

than the minimum external air temperature $\left(-7.1^{\circ} \mathrm{C}\right)$. This phenomenon can be explained considering the radiation heat transfer between solar panel and sky, which becomes important when no solar radiation is present.

In Case $\mathrm{B}$, heat extraction involves a decrease of the undisturbed ground temperature, consequently the total useful heat of the air-to-water heat pump increases from the first to the tenth year of operation. The exploitation of air increases over the years to remedy to the decrease of the water-to-water heat pump efficiency.

In Cases $\mathrm{C}$ and $\mathrm{D}$, the combination of solar and ground sources usually involves a higher mean temperature of the storage tank and therefore the operation period of the air-to-water heat pump is limited. Moreover, it determines the possibility to decrease the ground load; in the first year, the extraction of heat from the ground is less than about $30 \%$ of the extraction obtained in Case B. In the cold months the temperature of the heat-carrier fluid of PVT system is often lower than that of the ground loop; on the other side, in summertime the temperature of the heat-carrier fluid of PVT system is often higher than that, except during the night. However, since the mean temperature of the storage tank is higher than the temperature of the heat-carrier fluid from boreholes, the ground loop is always switched off in the warmer months. Therefore, the thermal contribution given by the solar source is about double that supplied by the ground source.

When heat is injected into the ground, the benefits in terms of COP of the water-to-water heat pump are not so high, since the ground source becomes more convenient during the night, when the DHW demand is limited. Moreover, the analysed borehole field cannot act as an energy storage due to its limited extension. Finally, the recharge of the ground increases its mean temperature, but, as a consequence of the heat release to the ground, slightly reduces the temperature of the heat-carrier fluid entering the storage tank. As a result, the difference of performances between the Cases $\mathrm{C}$ and $\mathrm{D}$ is negligible. 


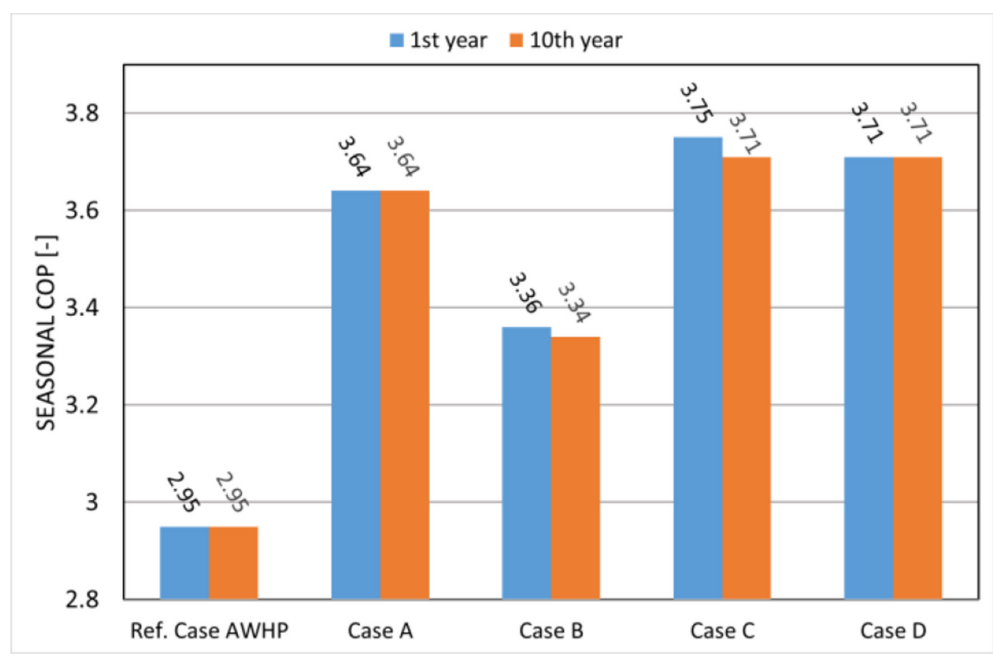

Figure 6: Seasonal energy efficiency of the different cases.

The electric production is increased thanks to the recharge of the ground, which allows to cool the PVT panels. However, since surplus of solar energy is available just when the temperature of the storage tank exceeds $30^{\circ} \mathrm{C}$, the cooling is limited. For this reason, compared to the Case A (PVT + air), the annual increase of electrical production is of $56 \mathrm{kWh}$ only (i.e. an increase of about $1 \%$ ). Considering that the recharge occurs during 502 hours per year, the advantage is obtained if the power of the circulators is less than $110 \mathrm{~W}$.

The aim of the simulations is to compare the energy performances of the analysed configurations. The reference value is the COP obtained from the simulation with a standard air-to-water heat pump which provides heat for the same building in the same boundary conditions. The results are reported in Fig. 6, for the first and the tenth year of simulation respectively. It is possible to conclude that all the examined system configurations provide a significant increase of efficiency compared to the reference solution (i.e. the system which has only the air-to-water heat pump system, the properties of the air-to-water heat pump are the same reported in Table 1 of the Section 5).

The configuration of Case B with the GSHP supplies the lowest COP. The configuration with PVT (Case A) devices assured a COP equal to 3.64. The most complex cases (C and D) provided very similar results. The recharge of the ground did not contribute to a significant increase of performance, as explained above. At the same time, it assures a constant performance over time, even if the configuration without recharge did not significantly decrease. As a result, it is possible to conclude that the complexity of the last two systems is not justified by a so low rise in terms of efficiency. If an adequate roof surface is present, the system with solar and air sources seems to be an effective solution.

\section{CONCLUSIONS}

The aim of this work was to investigate and to compare the energy performances of some multi-source systems, obtained the coupling heat pump technology with renewable energy sources. The analysis was carried out considering a single-family house located in Vicenza, Italy. Four system configurations have been examined and simulated through TRNSYS tool. Solar energy was provided by PVT panels, whose thermal and electrical performances have been calculated by means of a mathematical model developed in Matlab. Two configurations 
with air, ground and solar sources have been analysed. One of these did not consider any integration between solar and ground sources, whereas the other one considered the possibility of recharging the ground with solar energy which exceeded the energy demand of the building. In the latter solution, solar panels could balance ground loads, and at the same time increase their electrical production thanks to the cooling during the recharge mode. However, this configuration did not lead to significant advantages in terms of energy efficiency. The lowest seasonal COP, equal to 3.34 for the tenth year, was obtained for the system with ground and air sources. That was partially due to the limited depth of the two boreholes.

The seasonal COP of the system where solar and air sources were considered was equal to 3.64 , only slightly lower than those obtained for the more complex systems. The simulation results showed that for heating dominated buildings and so limited borehole fields, the configuration involving just solar and air sources was a good solution, despite the variability of those sources.

\begin{tabular}{lll} 
& & \multicolumn{2}{c}{ NOMENCLATURE } \\
$T$ & Temperature & {$[\mathrm{K}]$} \\
$U$ & Heat exchange coefficient & {$\left[\mathrm{W} /\left(\mathrm{m}^{2} \mathrm{~K}\right)\right]$} \\
$A$ & Area & {$\left[\mathrm{m}^{2}\right]$} \\
$m$ & mass flow rate & {$[\mathrm{kg} / \mathrm{s}]$} \\
$c_{p}$ & specific heat & {$[\mathrm{J} /(\mathrm{kg} \mathrm{K})$}
\end{tabular}

Subscripts

$\begin{array}{ll}\text { fluid } & \text { heat-carrier fluid } \\ \text { plate } & \text { roll-bond aluminium plate heat exchanger } \\ \text { in } & \text { inlet } \\ \text { out } & \text { outlet }\end{array}$

\section{REFERENCES}

[1] ISPRA - Istituto Superiore per la Protezione e la Ricerca Ambientale, Emissioni nazionali di gas serra, Rapporti 220/2015, 30 Aprile 2015, ISBN 978-88-448-0709-2 (in Italian).

[2] Emmi, G., Zarrella, A., De Carli, M. \& Galgaro, A., An analysis of solar assisted ground source heat pumps in cold climates. Energy Conversion and Management, 106, pp. 660-675, 2015.

http://dx.doi.org/10.1016/j.enconman.2015.10.016

[3] Trillat-Berdal, V., Souyri, B. \& Fraisse, G., Experimental study of a ground-coupled heat pump combined with thermal solar collectors. Energy and Buildings, 38, pp. 14771484, 2006. http://dx.doi.org/10.1016/j.enbuild.2006.04.005

[4] Eslami-nejad, P., Langlois, A., Chapuis, S., Bernier, M. \& Faraj, W., Solar heat injection into boreholes. Proceedings of the 4th Canadian Solar Buildings Conference, Toronto: Ontario, Canada, 2009.

[5] Kjellsson, E., Hellstrom, G. \& Perers, B., Optimization of systems with the combination of ground-source heat pump and solar collectors in dwellings. Energy, 35, pp. 1-7, 2009.

[6] Hawlader, M.N.A., Chou, S.K. \& Ullah, U.Z., The performance of a solar assisted heat pump water heating system. Applied Thermal Engineering, 21, pp. 1049-1065, 2001. http://dx.doi.org/10.1016/S1359-4311(00)00105-8 
[7] Dott, R., Genkinger, A. \& Afjei, T., System evaluation of combined solar \& heat pump systems. Energy Procedia, 30, pp. 562-570, 2012. http://dx.doi.org/10.1016/j.egypro.2012.11.066

[8] Bakker, M., Zondag, H.A., Elswijk, M.J., Strootman, K.J. \& Jong, M.J.M., Performance and costs of a roof-sized PV/thermal array combined with a ground coupled heat pump. Solar Energy, 78, pp. 331-339, 2005.

http://dx.doi.org/10.1016/j.solener.2004.09.019

[9] Leonforte, F., Ph.D. Thesis, Messa a punto e analisi prestazionale di un collettore ibrido fotovoltaico termico a fluido termovettore acqua, XXVI Ciclo, Politecnico di Milano (in Italian).

[10] Chow, T.T., Performance analysis of photovoltaic-thermal collector. Solar Energy, 75, pp. 143-152, 2003.

http://dx.doi.org/10.1016/j.solener.2003.07.001

[11] Herrando, M., Markides, C.N. \& Hellgardt, K., A UK-based assessment of hybrid PV and solar-thermal systems for domestic heating and power: system performance. Applied Energy, 122, pp. 288-309, 2014. http://dx.doi.org/10.1016/j.apenergy.2014.01.061

[12] Aste, N., Leonforte, F. \& Del Pero, C., Design, modeling and performance monitoring of a photovoltaic-thermal (PVT) water collector. Solar Energy, 112, pp. 85-99, 2015. http://dx.doi.org/10.1016/j.solener.2014.11.025

[13] Rejeb, O., Dhaou, H. \& Jemni, A., A numerical investigation of a photovoltaic thermal (PV/T) collector. Renewable Energy, 77, pp. 43-50, 2015. http://dx.doi.org/10.1016/j.renene.2014.12.012

[14] Zondag, H.A., Flat-plate PV-Thermal collectors and systems: a review. Renewable and Sustainable Energy Reviews, 12, pp. 891-959, 2008. http://dx.doi.org/10.1016/j.rser.2005.12.012

[15] U.S. Department of Energy-DOE, EnergyPlus Energy Simulation Software, available at: https://energyplus.net/weather-location/europe_wmo_region_6/ITA//ITA_ Vicenza.160940_IGDG

[16] Domestic hot water profiles. IEA/ECBCS Annex 42, available at: http://www.ecbcs. org/annexes/annex42.htm 